\title{
6. Australia and Latin America: Shared experiences and prospects for a new partnership
}

\author{
Don Kenyon and Pierre van der Eng
}

\section{Introduction}

Chapter 5 surveyed the development of the trade and business relations between Australia and the countries of Latin America during a period of more than 20 years. ${ }^{1}$ Apart from pointing to the fact that growth of these relations was carried by four key countries in Latin America, and by the diversification of trade and business relations towards manufactures and services, it did not explain the more fundamental reasons why trade and business relations increased. Identifying those reasons is important because it facilitates the discovery of the foundations for further growth and diversification, and the formulation of relevant government initiatives that may facilitate this process. That is the purpose of this chapter.

Section two will argue that several preconditions for an intensification of Australia's business relations with Latin America have been established. These are the result of the difficult but fundamental processes of trade liberalisation, market deregulation and structural reform in both Australia and key Latin American countries since the 1980s. The shared experience of these economic and trade policy reforms has greatly expanded the range of interests that Australia and the countries of Latin America have come to share in the international trade policy agenda. This also enhances the scope for closer trade and business relations.

Section three of this chapter will examine the scope for realising the promise that has long been considered to exist in building a closer trade and business partnership between Australia and Latin American countries. It will probe the increased scope that exists for pursuing shared trade policy objectives in

1 As in chapter five, Latin America is broadly defined to comprise South America and Central America, including the Caribbean, although further discussion will focus on Australia's main business partners in Latin America. 
the World Trade Organisation (WTO), as well as the opportunities for closer cooperation through new and important regional, plurilateral and bilateral economic and trade initiatives.

\section{New partners in globalisation: Shared experiences in structural reform and trade liberalisation}

Despite the remaining differences in the business environments of Australia and the countries of Latin America, the trade and business relations between Australia and Latin America have grown, as chapter 5 established. A major underlying reason for this development is the fact that Australia and key Latin American countries shared experiences in structural reform and trade liberalisation that created new business opportunities across the Pacific. To appreciate the importance of these developments it is relevant to sketch the situation that existed 25 to 30 years ago, and then trace the changes that have occurred since. In doing so, this section will set the scene for the discussion in section three of the opportunities that exist to enhance trade and business relations between Australia and Latin America.

Prior to the 1980s, Australia and Latin America regarded each other primarily as trade competitors rather than trade partners. There were a number of reasons for this. Perhaps the most important was that Australia and key Latin American countries such as Brazil, Argentina, Chile and Colombia were competitive exporters of the same temperate and subtropical agricultural products - such as beef, grains, sugar, fruit and fruit products - and minerals - especially iron ore in the case of Brazil - to northern hemisphere markets in Europe, North America and North Asia. Nevertheless, as exporters of agricultural products there was at the same time a shared interest in defending their agricultural trade against the protectionist agricultural policies of the European Community (EC) and the United States as exporting members of international commodity agreements and through the dispute settlement provisions of the General Agreement on Trade and Tariffs (GATT). ${ }^{2}$ However, the scope for this shared interest to foster closer cooperation on broader trade policy issues was muted by the primacy that Latin American countries gave to developing their international trade policy stances through the United Nations Conference on Trade and Development (UNCTAD) during the 1960s and 1970s. This limited the opportunities for effective coalition building in the pursuit of shared trade objectives in GATT trade negotiations, which tended to be dominated by the industrialised countries.

2 Don Kenyon and David Lee, The Struggle for Trade Liberalisation in Agriculture, 2006, pp. 25-7; 45-9. 
Both Australia and Latin American countries also followed essentially inwardlooking industry and trade policies. Industry policies pursued import substitution, high tariffs and non-tariff trade barriers to manufactured imports, managed exchange rates and foreign exchange controls, and a relatively high level of government involvement and management of the economy. Such policy stances also hindered the scope for broader trade and business links across the Pacific that could have been a basis upon which to dilute competitive relations concerning agricultural exports. In addition, it meant that Australia and Latin American countries found each other on opposite sides of the divide between less-developed and developed countries characteristic of international trade discussions and negotiations, especially in successive GATT rounds of negotiations on trade liberalisation, as well as in UNCTAD.

Another dividing factor was that Australia and the countries of Latin America pursued different priorities regarding regional economic integration. For both Australia and Latin America during the 1970s and 1980s the priorities were north-south, rather than east-west. In the case of Australia, besides maintaining its relations with the United States, the trade policy priorities were oriented towards fostering relations with newly emerging markets in East Asia, particularly Japan, South Korea, the ASEAN countries, and more recently China. Such efforts were focused on Australia's exports of the commodities produced by Australia's agricultural and mining industries. In the case of Latin American countries, considerable attention was given during the 1960 s and 1970s to fostering regional economic integration. In fact, regional integration efforts during this period were driven by the aim of creating a more effective developing country counterweight to the dominance of the United States in western hemisphere trade. But the inward-looking trade and industry policies of Latin American countries made effective cooperation to that end difficult.

By the early 1980s, the successive shocks caused by oil price hikes, long periods of stagflation in the mature industrial economies of Europe and North America, and the emergence of an industrially more competitive Japan-followed soon after by South Korea; Taiwan; Singapore and Hong Kong; key ASEAN countries; and China-were creating a new situation that called on countries to consider ways to increase their global competitiveness. Tariff protection and economic systems with a high degree of government intervention were giving way to more open trade policies, deregulated industries and floating exchange rates. Australia and Latin American countries were caught up in this wave of renewed globalisation.

In Australia, a period of recession, rising unemployment and soaring current account deficits during the late 1970s and early 1980s ushered in a period of fundamental change in economic and trade policy from 1982. It saw the deregulation of currency and exchange controls and the floating of the Australian 
dollar, the dismantling of the protective system of high tariffs on manufactured products, deregulation and privatisation of many previously governmentcontrolled and owned industries, followed by regulatory reforms of the financial sector and the lifting of restrictions on foreign investment. ${ }^{3}$ In all, by the early 1990s Australia had developed an integrated and internationally competitive financial sector, as well as a significantly reduced role for government in the management of the economy. And during the 1990s, the different sectors of the Australian economy became increasingly open and internationally competitive.

Similar changes took hold in key Latin American countries, albeit that the process of economic reform was in some countries interrupted by major financial crises that resulted in two steps forward, one step back. In Mexico, the external debt crisis of 1982 gave rise to a program of wide-ranging economic reforms. Mexico joined GATT in 1986, which marked the start of a process of reducing tariff protection as well as introducing programs of privatisation and regulatory reform. Further financial crises in 1990 and 1994 halted the process temporarily, but the entry into force of the North American Free Trade Agreement (NAFTA) with Canada and the United States in 1994, in particular provided new momentum for trade liberalisation in Mexico and the country's integration into global markets.

In the case of Brazil, the process of integration into global markets started in earnest in 1994, after several years of high to hyperinflation. In that year, the implementation of the Plan Real stabilised the currency exchange rate relative to the US dollar in order to address the debilitating problem of inflation. This was supported by a vigorous program of privatisation and deregulation that during the rest of the 1990s opened up the economy to market-based principles. The changes were not without difficulties, particularly in terms of the threat of inflation and currency convertibility. Nevertheless, prudent economic management secured economic stability and significant economic growth followed, to the extent that the currency appreciated during much of the 2000s and remained relatively stable after the Global Financial Crisis of 2008.

In the early 1990s, Argentina took similar measures to Brazil in order to resolve the problem of debilitating high inflation. It too suffered the consequences of heavy reliance on government management of the economy. In 1991 the peso was pegged to the US dollar, while the government imposed drastic discipline on public expenditure. As in Brazil and Mexico, processes of privatisation and deregulation, as well as reducing barriers to foreign trade and investment, allowed economic recovery and growth. But the process was interrupted in 2002, when it proved impossible to sustain pegging its currency to the US

3 Kenyon and Lee 2006, op. cit., note 2, pp. 52-3. 
dollar. Further policy action, such as abandoning full convertibility with the US dollar, stabilised the currency a year later and sustained a new process of recovery and growth.

In the case of Chile, economic reforms had already begun in the mid-1970s, when the government opted to lift barriers to trade and investment and embark on a process of privatisation and financial market deregulation. These were the foundations for significant economic growth during the 1980s and 1990s, which was sustained by Chile's increasing engagement in global markets. Chile's foreign trade has expanded rapidly following the global deregulation of trade barriers since the late 1980s. Table 6.1 shows that Chile is now one of the Latin American countries with the lowest trade tariffs.

Table 6.1 Tariffs in Australia and Latin American countries, 2011

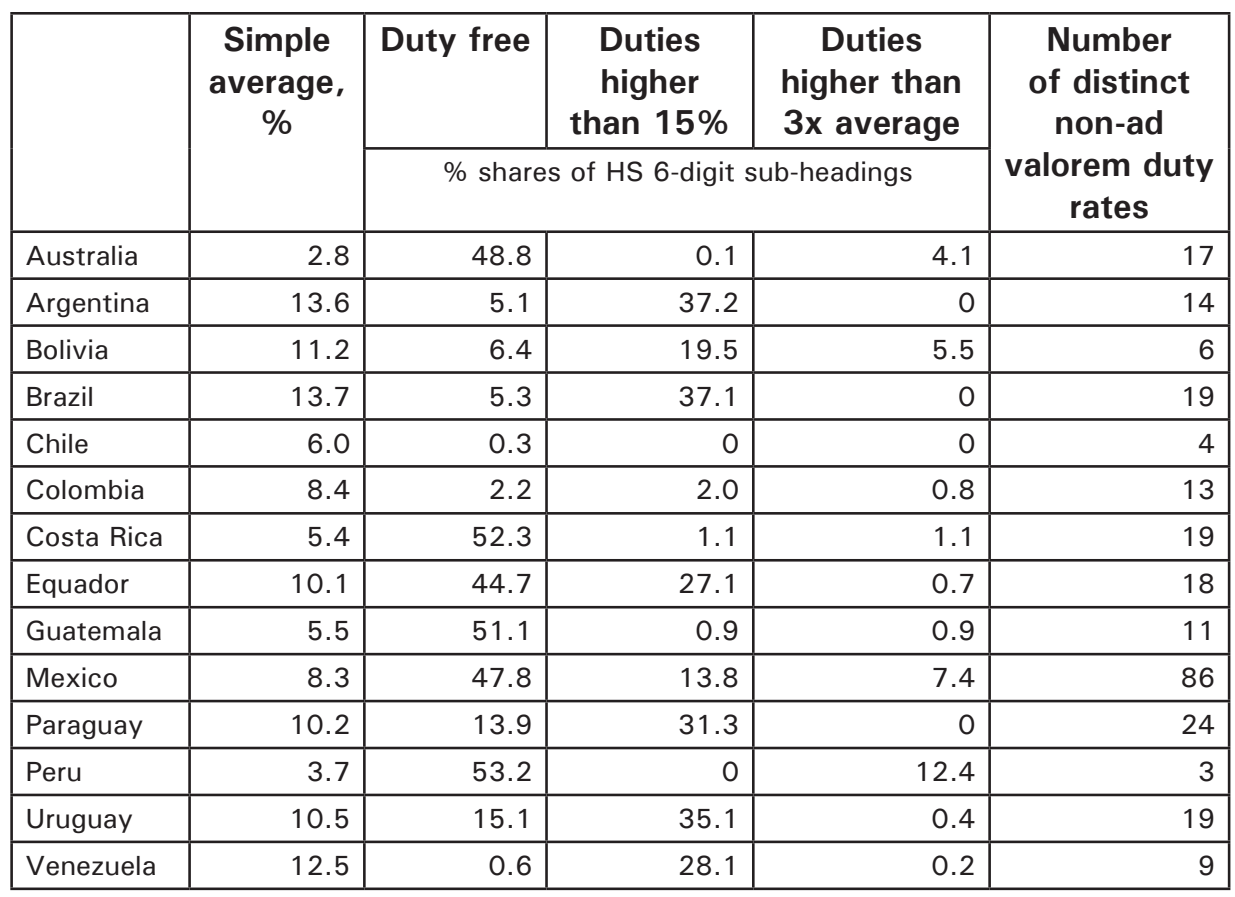

Note: Most favoured nation status applied in all cases. HS is the Harmonised System to classify commodity trade.

Source: WTO, 2012, pp. 2-6.

These four Latin American countries embarked on processes of deregulation, privatisation and liberalisation of trade and investment policies for their own reasons and with their own institutional legacies. A closer look reveals significant differences between each of them, as well as with other Latin 
American countries. ${ }^{4}$ Hence, their experiences cannot be readily extrapolated to other countries in the region. In several cases, such as Venezuela and Ecuador, countries did not experience such changes, while in others, such as Colombia and Peru, similar changes occurred much more recently. Nevertheless, sketching the developments in these key countries helps to explain why they dominate the business relations of Latin America with Australia. The main conclusion that can be drawn from these sketches is that since the 1970s these four countries and Australia have undergone similar processes of economic change that have resulted in their increasing engagement with global markets. At the same time, it should be noted that global trade of goods and services, as well as investment flows, increased rapidly during the 1990s and 2000s, to a much greater degree than had ever occurred before. ${ }^{5}$ This growth was sustained by global adherence to trade liberalisation following the end of communism in Eastern Europe around 1990, the successful conclusion of the GATT Uruguay Round (1986-93), and continued efforts to reduce trade barriers multilaterally, particularly for services, under the mandate of the WTO. Consequently, during the last 20 to 25 years these countries enhanced their ability to participate in international trade and business, and consequently benefit from it.

A major spur to these fundamental reforms in both Australia and Latin America was the realisation that in a global economy increasingly dominated by large multinational corporations - and in which trade in services across borders was becoming increasingly important-policies of import substitution supported by high levels of protection had run their course. While in earlier decades such policies had sustained economic growth, structural change and growing employment opportunities in industrial sectors, by the early 1980s it became increasingly clear that the resolution of global economic stagnation required a change of tack.

The reform programs also came at a fortuitous time for both the global economy and the future of business relations across the Pacific. The GATT Uruguay Round of multilateral trade negotiations had been languishing since its launch in the midst of the global economic crisis of the mid-1980s. The rollout of domestic economic reform and trade liberalisation programs across the industrialised and less-developed world through the 1980s enabled the Uruguay Round to be successfully concluded in 1993. This delivered several outcomes that fostered global trade, including ground-breaking agreements on agriculture and textiles; significant further reductions in industrial tariffs around the world; the creation

\footnotetext{
4 Nevertheless, these policy changes affected Latin America to a significant extent and were hailed as Latin America's 'New Economic Model', which fostered FDI inflows during the 1990s: see e.g., Michael Mortimore, 'Corporate Strategies for FDI in the Context of Latin America's New Economic Model', World Development, 2000, 28, pp. 1611-26.

5 WTO, International Trade Statistics 2009, Geneva: World Trade Organization, 2009, p. 173; UNCTAD, World Investment Report 2009, New York: United Nations Conference on Trade and Development, 2009, p. 4.
} 
of a new set of trade rules for the liberalisation of trade in services; and new agreements to enforce intellectual property rights, to strengthen the GATT/ WTO dispute settlement system, and to limit the use of subsidies and to impose greater discipline on technical barriers to trade, including standards and sanitary and phytosanitary restrictions.

The successful conclusion of the Uruguay Round negotiations was also of particular importance in giving new impetus to the future prospects for the trade and business relationship between Australia and Latin America. A major trade and political problem that the GATT negotiations had to confront was the challenge to the major trade interests of both Australia and Latin American countries posed by the agricultural policies of the then European Community (EC), the United States, Japan and South Korea. The export subsidy war on agriculture between the EC and the United States had brought world agricultural trade to a crisis point by the beginning of the Uruguay Round in 1986. Australia took the initiative to bring 14 developed and developing countries together in a coalition to fight this major trade bloc. Five Latin American countries-Argentina, Brazil, Chile, Colombia and Uruguay - became members of this Cairns Group (CG) of agricultural exporting countries. ${ }^{6}$ The success of the CG in the negotiations in helping to bring the export subsidy war on agriculture to an end demonstrated that developed and less-developed countries could work closely together to achieve common trade policy objectives. The confidence established during these negotiations dispelled much of the earlier reticence towards working together that had previously been a feature of relations between Australia and Latin American countries, at least at an intergovernmental level. The shared experience of the CG in the Uruguay Round did much to breathe new life into the trade and business relationship between Australia and Latin America.

Hence, by the mid-1990s, the prospects for future partnership between Australia and Latin America had been transformed. The old competitive default setting over agriculture was largely a thing of the past. The divide between developed and less-developed countries was no longer a barrier to closer trade cooperation, both in WTO and in bilateral trade relations. As a consequence, the promise of closer trade and business relations which had proved elusive in the past showed better prospects of being fulfilled. In addition, the shared experience of implementing economic and trade reform policies put Australia and key Latin American countries on more comparable paths of economic and trade openness, which created new opportunities for closer business relations across the Pacific.

6 During the Uruguay Round negotiations 14 countries constituted the CG: Argentina, Australia, Brazil, Canada, Chile, Colombia, Fiji, Hungary, Indonesia, Malaysia, New Zealand, Philippines, Thailand and Uruguay. After the end of the Uruguay Round, Fiji and Hungary left the CG, but five additional Latin American countries - Bolivia, Costa Rica, Guatemala, Paraguay and Peru-plus Pakistan and South Africa have subsequently joined, bringing current membership to 19 countries. 
As chapter 5 has already noted, a combination of factors contributed to a new foundation for the expansion of business relations between Australia and Latin America: the experience of the Uruguay Round; the ongoing processes of liberalisation and deregulation; the increasing participation in global markets; and the ongoing processes of growth and structural change in Australia and the four key countries in Latin America. It had put them through comparable challenges and experiences, and contributed to the development of more open, increasingly advanced and internationally competitive economies. This was particularly the case in regard to the conversion of non-tariff trade barriers on agriculture into tariffs, and the reduction of tariff protection, which forced companies in these countries to restructure in response to the pressures of international markets. It obliged industries in these countries to readjust according to the comparative advantage of their economies.

Increasing investment opportunities combined with reduced barriers to investment fostered this process; it is one of the reasons why Australia-based mining companies such as BHP Billiton and Rio Tinto increased their engagement in operations in Latin America, and why Brazilian company Vale established coal mining operations in Australia. In addition, following privatisation and increased liquidity, there is increased Australian investment in infrastructure such as roads, airports and ports, telecommunications services, as well as real estate in Latin America, and vice versa. Likewise, new opportunities have opened up in tourism, education, and professional services such as engineering, architecture and accounting.

As noted above, this process of growing business relations between Australia and Latin America took place in a context of growing global markets. Consequently, the magnitude of change in the business relations between Australia and Latin America is easily overlooked in this international context. Even though primary commodities are still important in the trade relationship, as noted in chapter 5 , a significant change has been the diversification of trade relations to encompass a greater range of manufactured products and services. For example, the role of computer peripherals and combustion engines in Mexico's exports to Australia in recent years is directly related to Mexico's engagement in NAFTA with Canada and the United States, and its process of structural change; NAFTA encouraged American and Canadian firms to establish manufacturing assembly facilities in Mexico for export purposes.

While the processes of economic change have increased the competitiveness of Australia and the four Latin American countries discussed in this section, it should be noted that a range of issues remain, particularly for the Latin American countries. They range from the issues that shape the business environment in these countries - as discussed in chapter 5-to broader issues such as labour market rigidities and the significant and tenacious problem of income inequality 
and poverty. In addition, processes of deregulation are still incomplete in several sectors of Latin American economies, particularly financial services. Such resulting regulatory divergences continue to impose significant impediments to goods and services trade across the Pacific. Arguably, these issues are more or less important depending on the particular country concerned. For example, Chile's business environment is more comparable with Australia's than that of other countries, as chapter 5 established.

In this context, disappointment has been expressed in Latin American countries in recent years with how slowly the benefits of economic reform are emerging. A comparison is sometimes made with the stellar growth performance in East Asian economies following the economic reforms implemented there in the 1970s and 1980s. Some have concluded that Latin American countries' failure to deliver similar economic results is due to the inadequacies or inappropriateness of 'neoliberal' economic policies to Latin America. ${ }^{7}$ Walton examined two alternative concepts of 'neo-liberalism': a narrow interpretation that refers to a limited shift towards greater reliance on market forces; and a broad interpretation involving a 'wholesale change in the relationship between the state and society with a more vigorous embrace of the market being part of a generalised withdrawal of state provisioning and action' ${ }^{8}$ He concluded that the reform programs pursued in Latin American countries accord more with the first interpretation. They comprise fiscal and monetary reforms and trade liberalisation at a macroeconomic level, as well as privatisation, financial sector deepening, capital market opening, tax reform and property rights reform. Walton also concluded that these reforms continue to retain a significant role for governments in social provisioning, and that they have generally been positive for economic development. The extent to which this mix of reform policies has failed to yield the full anticipated benefits in terms of greater prosperity for the peoples of Latin American countries is due more to the incomplete implementation of the reform programs in particular countries than to their inadequacies or shortcomings.

\section{Towards a new partnership: Multilateral, regional and bilateral}

The shared experiences of the past decades of economic reform and trade liberalisation programs have put Australia and key Latin American countries

\footnotetext{
7 Kurt Weyland, 'Assessing Latin American Neoliberalism: Introduction to A Debate', Latin American Research Review, 2004, 39 (3), pp. 143-9; Eric Hershberg and Fred Rosen, (eds), Latin America after Neoliberalism: Turning the Tide in the 21st Century? New York: The New Press, 2006.

8 Walton, Michael, 'Neoliberalism in Latin America: Good Bad or Incomplete?', Latin American Research Review, 2004, 39 (3), pp.165-83.
} 
on a comparable path of development that is characterised by greater openness. Nevertheless, the continued diversity of business environments in Latin America, as well as between Australia and Latin American countries, makes it necessary for these countries to pursue a range of different, but interrelated multilateral, plurilateral and bilateral options in an effort to broaden and deepen their trade and business relationships. This section will offer reflections on the opportunities that exist to that effect.

Table 6.2 Membership of international organisations and regional trade agreements relevant to Australia-Latin America trade and business relations, February 2013

\begin{tabular}{|l|l|l|l|l|l|l|l|l|}
\hline & \multicolumn{3}{|c|}{ International } & \multicolumn{5}{c|}{ Regional } \\
\hline & WTO & UNCTAD & APEC & LAIA & Mercosur & CACM & CAFTA & NAFTA \\
\hline Australia & $\sqrt{ }$ & $\sqrt{ }$ & $\sqrt{ }$ & & & & & \\
\hline USA & $\sqrt{ }$ & $\sqrt{ }$ & $\sqrt{ }$ & & & & $\sqrt{ }$ & $\sqrt{ }$ \\
\hline Argentina & $\sqrt{ }$ & $\sqrt{ }$ & & $\sqrt{ }$ & $\sqrt{ }$ & & & \\
\hline Bolivia & $\sqrt{ }$ & $\sqrt{ }$ & & $\sqrt{ }$ & $\sqrt{ }$ & & & \\
\hline Brazil & $\sqrt{ }$ & $\sqrt{ }$ & & $\sqrt{ }$ & $\sqrt{ }$ & & & \\
\hline Chile & $\sqrt{ }$ & $\sqrt{ }$ & $\sqrt{ }$ & $\sqrt{ }$ & & & & \\
\hline Colombia & $\sqrt{ }$ & $\sqrt{ }$ & & $\sqrt{ }$ & & & & \\
\hline Costa Rica & $\sqrt{ }$ & $\sqrt{ }$ & & & & $\sqrt{ }$ & $\sqrt{ }$ & \\
\hline Cuba & $\sqrt{ }$ & $\sqrt{ }$ & & $\sqrt{ }$ & & & & \\
\hline $\begin{array}{l}\text { Dominican } \\
\text { Rep. }\end{array}$ & $\sqrt{ }$ & $\sqrt{ }$ & & & & & $\sqrt{ }$ & \\
\hline Ecuador & $\sqrt{ }$ & $\sqrt{ }$ & & $\sqrt{ }$ & & & & \\
\hline El Salvador & $\sqrt{ }$ & $\sqrt{ }$ & & & & $\sqrt{ }$ & $\sqrt{ }$ & \\
\hline Guatemala & $\sqrt{ }$ & $\sqrt{ }$ & & & & $\sqrt{ }$ & $\sqrt{ }$ & \\
\hline Honduras & $\sqrt{ }$ & $\sqrt{ }$ & & & & $\sqrt{ }$ & $\sqrt{ }$ & \\
\hline Mexico & $\sqrt{ }$ & $\sqrt{ }$ & $\sqrt{ }$ & $\sqrt{ }$ & & & & $\sqrt{ }$ \\
\hline Nicaragua & $\sqrt{ }$ & $\sqrt{ }$ & & & & $\sqrt{ }$ & $\sqrt{ }$ & \\
\hline Paraguay & $\sqrt{ }$ & $\sqrt{ }$ & & $\sqrt{ }$ & $\sqrt{ }$ & & & \\
\hline Peru & $\sqrt{ }$ & $\sqrt{ }$ & $\sqrt{ }$ & $\sqrt{ }$ & & & & \\
\hline Uruguay & $\sqrt{ }$ & $\sqrt{ }$ & & $\sqrt{ }$ & $\sqrt{ }$ & & & \\
\hline Venezuela & $\sqrt{ }$ & $\sqrt{ }$ & & $\sqrt{ }$ & & & & \\
\hline
\end{tabular}

Notes: WTO = World Trade Organization; UNCTAD = United Nations Conference for Trade and Development; $\mathrm{APEC}=$ Asia-Pacific Economic Cooperation; LAIA $=$ Latin American Integration Association; Mercosur = Mercado Común del Sur [Southern Common Market]; CACM $=$ Central American Common Market, CAFTA $=$ Central American Free Trade Agreement, NAFTA $=$ North American Free Trade Agreement.

Sources: WTO, RTA Data Base, http://rtais.wto.org; UNCTAD, http://www.unctad.org. 
Table 6.2 shows that Australia and all the key countries of Latin America share only two forums that could be the basis for multi-country discussions on common interests in advancing trade and business relations: the World Trade Organization (WTO) and the United Nations Conference on Trade and Development (UNCTAD). UNCTAD is effectively a forum that allows less-developed countries to draw attention to their concerns about international trade and investment issues, and to develop solutions in cooperation with developed countries. It is not a forum in which multi-country coalitions can generate leverage in order to advance the agenda of trade liberalisation. Nor does UNCTAD provide a forum for trade negotiations or constitute a body of trade rules in the way that the WTO does. Table 6.2 also shows that several Latin American countries also participate in regional trade agreements, also including the United States. However, the nonparticipation of Australia makes it difficult for them to be seen as vehicles to advance common interests. In effect, that leaves the WTO as the major international forum in which Australia and countries of Latin America can cooperate for the purpose of forging ties that may benefit mutual interests in trade liberalisation.

\section{Multilateral partnerships}

From the high tide of deregulation and globalisation of the mid-1990s, public expectations of the WTO in more recent years appear to have receded, especially as a result of the difficulties of bringing the 11-year-old WTO Doha Development Agenda trade negotiations to a successful conclusion. However, such judgements underestimate the capacity of the WTO to continue to deliver real benefits for trade liberalisation and trade cooperation, and to maintain an open world trading system from which all member countries benefit. The role of the WTO as a forum for periodic trade liberalisation negotiations receives the most public attention. But the GATT/WTO system also constitutes a body of international trade law that applies to its 159 members. This covers trade in goods and services, as well as intellectual property rights. It also includes a dispute settlement system which has amply demonstrated its capacity to ensure adherence by member countries to the trade rules.

Beginning with an initial membership of 23 mainly industrialised countries in 1947, GATT focused during its first 30 years on negotiating reductions in import tariffs that affected manufactured goods. Its membership continued to grow, encompassing 123 less-developed and developed countries by 1986 at the beginning of the Uruguay Round negotiations. From the Tokyo Round of negotiations (1973-79), GATT increasingly began to bring non-tariff trade barriers into its negotiating agendas. The Uruguay Round extended the trade rules to services and intellectual property issues and, as section two indicated, achieved an agreement which finally brought agriculture and textiles more fully under the trade-liberalising GATT rules. It also created a new dispute settlement 
system, which significantly strengthened the capacity of WTO members to ensure that the trade rules on both goods and services were respected. The key element of the new dispute settlement system is the 'reverse consensus' rule, under which judgements against a member found to be in breach of the trade rules can only be rejected by consensus among member countries. Previously, reports had to be adopted by consensus, enabling a defendant in a GATT rules case effectively to veto judgements being made against it. The Uruguay Round also achieved another breakthrough important for boosting the credibility of the WTO system in that it effectively ended the north/south or developed/ less-developed international divide, which had previously limited the active participation in periodic trade liberalisation negotiations to a relatively small number of industrialised countries.

In the more open, less autarchic, increasingly globalising environment of the late 1980s, the major less-developed countries, including all Latin American countries, participated very actively in the Uruguay Round. It is perhaps appropriate to note at this point that Mexico only acceded to the GATT on the eve of the Uruguay Round and thereafter participated enthusiastically throughout the eight years of negotiations. Not only did these negotiations see the full participation of less-developed countries for the first time, but the Uruguay Round ushered in another new phenomenon; that of developed and less-developed countries working actively together in pragmatic coalitions to achieve outcomes on a subject-by-subject or issue-by-issue basis. The standout example in the Uruguay Round was the Cairns Group, discussed in section two. But the Cairns Group was not the only instance of north/south coalitions that drove the agenda of negotiations during the Uruguay Round. Prior even to the launch of the negotiations in 1986, the 'Group of 48' developed and lessdeveloped countries co-convened by the Swiss and Colombian ambassadors in Geneva and also including Chile, Mexico and Uruguay from Latin America, was influential in achieving a mandate for the negotiations of sufficiently broad scope to ensure that the trade negotiating priorities of both developed and developing countries were adequately covered. ${ }^{9}$

Thus the Uruguay Round firmly established the practice of developed and lessdeveloped countries working together in pragmatic coalitions to realise shared trade liberalisation objectives. This practice has been developed further during the Doha Development Agenda negotiations. Moreover, since the beginning of the Uruguay round, a further 36 countries have joined the WTO, including China and Russia, so that the organisation today is more than ever a genuine multilateral trade organisation that brings together both developed and less-developed countries in the pursuit of continuing trade liberalisation. Agriculture is again

9 Preeg, Ernest H., Traders in a Brave New World: The Uruguay Round and the Future of the International Trading System, Chicago: The University of Chicago Press, 1995, pp. 3-6; 58-62. 
the most high profile example of north/south coalition-building in the Doha negotiations. Consequently, the Cairns Group continues to play an active role and five additional Latin American countries-Bolivia, Costa Rica, Guatemala, Paraguay and Peru - have joined. Brazil also brought together the 'Group of 20' less-developed countries to work on agriculture in the Doha negotiations. These coalitions impact on the configuration of small groups playing a key role in reaching compromises on agriculture and more broadly across the negotiations. The geometry has varied, for example, from FIPs (Five Interested Parties: US, EU, Brazil, India and Australia), G6 (FIPs plus Japan), G4 (US, EU, Brazil, India), G5 (US, EU, Brazil, India and China) and most recently G7 (G5 plus Japan and Australia) and G11 (G7 plus Argentina and Canada, as well as South Africa and Mauritius for the African, Caribbean and Pacific group of countries).

The unilateral trade liberalisation programs undertaken by Latin American countries since the 1980s also resulted in the circumstance of a number of these countries now having interests in other elements of the Doha negotiating agenda that are more in line with the interests of developed countries such as Australia than with other less-developed countries. The negotiations on issues such as industrial tariff liberalisation, services and WTO rules are prime examples. There are several areas of negotiations on rules and services issues where Australia has been working in coalition groupings with some combination of either Argentina, Brazil, Mexico or Chile, such as fisheries subsidies, the 'Colorado group' on trade facilitation issues, the mutual recognition of professional qualifications for architects and engineers, computer related services, logistics and maritime transport. ${ }^{10}$ Since the creation of the 'Really Good Friends of Services' group of countries in 2005, six Latin American countries - Chile, Colombia, Costa Rica, Mexico, Panama and Peru - have participated in plurilateral negotiations along with Australia, the United States, the European Union and others, to reach a plurilateral agreement on services trade liberalisation following the impasse facing the Doha negotiations. Australia and Latin American countries have also shared interests in specific dispute settlement cases in which they work together in the WTO. Such cases provide significant opportunities to develop trade policy and business links further. Prominent examples in recent years have been the 'Byrd Amendment' case (2001) brought by Australia, Brazil, Chile, and others including the European Union against an item of US antidumping legislation, and the 'Sugar Export Subsidy' case against the European Union that was brought to the WTO jointly by Australia, Brazil and Thailand. ${ }^{11}$ Both of these joint actions went through the entire WTO dispute settlement procedure: panel investigation; the appeals process; and arbitration. The WTO

10 Diego-Fernández, Mateo, 'Trade Negotiations Make Strange Bedfellows', World Trade Review, 2008, 7, pp. 423-53, 450 .

11 Ibid., p. 442. 
dispute settlement system is not only an effective mechanism with which to enforce adherence to the trade rules: through its judgements, the system also makes significant contributions to trade liberalisation.

A third way in which the WTO contributes to trade liberalisation is through the accession negotiating process. All countries that accede to the WTO-and the GATT prior to 1 January 1995-are required to negotiate the terms of their accession. These terms aim to reflect not only the collectivity of commitments made by existing WTO members up to the most recently concluded trade negotiating round; they also frequently seek to extract concessions that go beyond existing multilateral commitments, thereby foreshadowing trade liberalising objectives of future rounds of negotiations. Thus, for accessions that followed the establishment of the WTO in 1994 - such as in the cases of China and the Customs Territory of Taiwan-WTO members have sought and secured 'WTO plus' trade liberalisation commitments from the newly acceding countries. In this way, the WTO accession process also contributes to trade liberalisation.

For all these reasons, the WTO provides a valuable forum for trade policy cooperation between Australia and Latin American countries that could foster trade and business links across the Pacific. Joint action in pursuing shared trade liberalisation objectives in multilateral rounds such as the Uruguay Round in the past and the current Doha Development Agenda bring Australian and Latin American trade policy objectives closer together. They can be especially effective in dealing with international trade problems such as agricultural and other subsidies that can only be successfully negotiated multilaterally. Joint action in dispute settlement cases and accession negotiations dealing with shared trade problems strengthens habits of working together and the same time increases understandings across the Pacific. Finally, the more Australia and Latin American countries work together in the WTO, the more likely they are to find common cause in developing a future post-Doha agenda for the WTO. This may be especially relevant with regard to dealing with the 'behind the border' barriers to trade such as product standards and domestic services regulations, which are becoming increasingly important as major impediments to trade and investment flows around the globe.

\section{Plurilateral partnerships}

The economic and trade liberalisation programs implemented by Latin American countries from the 1980s were followed by the rapid conclusion of regional and extra-regional agreements with major trading partners of the northern hemisphere, with Mexico and Chile leading the way. Shortly following its accession to GATT in 1986 and participation in the Uruguay Round negotiations, Mexico concluded the NAFTA with the United States and Canada (1994). This was 
followed by the Mexico-EU agreement (2000) and the Mexico-EFTA agreement (2001). Chile concluded agreements with the EU (2002), the United States (2004) and EFTA (2004). Chile in particular has continued an active pursuit of Free Trade Agreements (FTAs) with a wide range of countries: it now has FTAs with no less than 54 trading partners, including Australia (2009). Similarly, FTAs now cover over 90 per cent of Mexico's total trade. ${ }^{12}$

These agreements are for the most part 'new generation' FTAs in the sense that they aim to be 'WTO plus', not only in terms of satisfying the tariff liberalisation requirements of GATT article XXIV on free trade areas and customs unions, but in going beyond the Uruguay Round commitments in the new WTO areas of services trade liberalisation and intellectual property protection. They also achieve new, more liberal commitments in domestic regulatory policies that impact on trade and investment flows, such as product standards, domestic services regulations, public procurement policies, investment restrictions, and protection and business visas.

This is not the place for a detailed analysis of the extent to which these 'new generation' FTAs entered into by Mexico and Chile and other Latin American countries are indeed 'WTO plus' or, possibly in some respects, 'WTO minus' in their detailed provisions. Marconini analysed this issue for services, while Sauvé examined it for investment. ${ }^{13}$ Suffice to say that the existence of these agreements that have been entered into by Latin American countries since the establishment of the WTO in 1994 bear witness to their readiness to extend beyond tariffs liberalisation in agreements that aim to open markets. The scope of these agreements is recognition also that in continuing down this broadly based path of opening markets, future outcomes may best be pursued by negotiating directly on the domestic regulations that hinder trade and investment flows, rather than continuing to focus on border measures such as 'market access' and 'national treatment' commitments in the case of services under the General Agreement on Trade in Services (GATS). ${ }^{14}$

A recent plurilateral development that may further strengthen Australia's business relations with the Latin American region is the process by which the G20 group now operates. The group was established in 1999 in the wake of the 1997 Asian crisis, with the aim of stabilising global financial markets. Its role was heightened during the recent Global Financial Crisis. ${ }^{15}$ This process grew

12 JEG, Australia-Mexico Joint Experts Group on Strengthening Bilateral Economic Relations: Joint Report, 2009 , p. 31.

13 Mario Marconini, 'Services in Regional Agreements between Latin American and Developed Countries', CEPAL Serie Commercio Internacional No.71. (ECLAC), 2006; Pierre Sauvé, 'Trade and Investment Rules: Latin American Perspectives', CEPAL Serie Comercio Internacional No.66. (ECLAC), 2006.

14 Marconini, op. cit., note 13.

15 The G20 members are Argentina, Australia, Brazil, Canada, China, France, Germany, India, Indonesia, Italy, Japan, Mexico, Russia, Saudi Arabia, South Africa, South Korea, Turkey, the United Kingdom and the United States, as well as the European Union. 
out of a realisation that other existing arrangements for international financial management and economic cooperation were not sufficiently representative of the countries that were required to find solutions to the crisis. As a result, the G20 summits have recently emerged as the principal forum for global economic cooperation, and may continue in this role in the future. Current G20 members account for more than 85 per cent of global GDP and 80 per cent of global trade. Australia and three major Latin American countries-Argentina, Brazil and Mexico-are members.

At their meetings in Washington in 2008, and London and Pittsburgh in 2009, G20 leaders pledged, inter alia, to develop programs for strong, sustainable, balanced growth subject to peer review; to refrain from protectionist trade measures; and to seek an ambitious as well as balanced conclusion to the Doha negotiations. Successive G20 summits in June 2010 in Toronto and Seoul in November 2010 placed increasing emphasis on core strategies for recovery from the global financial crisis, reform of the international financial regulatory system, and reform of the IMF. The G20's focus on crisis and recovery has been successful in the sense that trade protection or capital controls have hardly been used to respond to the crisis. But with the 2008 crisis and its aftermath fading, the group has become increasingly engaged with relatively marginal issues during its recent summits in Cannes in November 2011 and Los Cabos in June 2012. Nevertheless, the G20 dialogue will provide useful opportunities for exchanges between Australia and the three Latin American members of the G20, on sustainable economic growth and financial stability objectives in an open trade environment, that are also likely to strengthen trade and business links across the Pacific.

The Asia-Pacific Economic Cooperation (APEC) forum is another trans-Pacific plurilateral grouping that can make a significant contribution to building closer trade and investment links with Latin America, despite the non-membership of economic heavyweights Argentina and Brazil. As Table 2 shows, along with Australia, Chile, Mexico and Peru are members. ${ }^{16}$ APEC is more specifically focused on trade integration than the G20, but it is well placed to contribute to supporting and delivering on the broader agenda of the G20, involving trade and economic growth. Having already made a significant contribution over the past two decades to the liberalisation of physical trade barriers in the APEC region - and more globally through APEC's influence on multilateral negotiations - APEC members are now increasingly focused on reducing

16 APEC's 21 members are Australia, Brunei, Canada, Chile, China, Hong Kong, Indonesia, Japan, South Korea, Malaysia, Mexico, New Zealand, PNG, Peru, The Philippines, Russia, Singapore, Taiwan, Thailand, the United States and Vietnam. 
regulatory barriers to trade, especially in relation to competition policy, customs procedures, the mutual recognition of standards, and reducing trade barriers imposed by domestic regulations on services.

In the longer term the Australian government is interested in the development of an overarching 'Free Trade Area of the Asia-Pacific' (FTAAP). This could include all APEC-member economies and is therefore likely to require a lengthy period of preparatory work. While the FTAAP initiative had some resonance in APEC-member countries Chile, Mexico and Peru, particularly in the business world, it remains to be seen whether the governments of these countries will be interested in participating in such an overarching FTA. However, the current APEC focus and work program on regulatory trade reform will of itself continue to make a valuable contribution to strengthening business links between Australia and the Latin American members of APEC.

Finally, plans have been underway since 2008 for a Trans Pacific Partnership Agreement (TPP) that originally brought together Australia, Brunei, Chile, New Zealand, Singapore, Peru, Vietnam and the United States. Subsequently, Canada, Mexico, Malaysia and Vietnam have joined the group, and most recentlyMarch 2013-Japan expressed willingness to join. TPP is another important initiative strengthening links across the Pacific. ${ }^{17}$ Participants are expected to aim for a 'WTO plus' plurilateral agreement that increases economic integration in the Asia-Pacific region, especially as membership is expected to increase over time. At the first round of negotiations in Melbourne in March 2010, the then Australian Minister of Trade said that the TPP agreement 'represents a pathway towards achieving APEC's long-term goal of a Free Trade Area of the Asia-Pacific' ${ }^{18}$ Hence, the TPP could be a step towards multilateralising or at least regionalising existing FTAs between TPP partners, although at the second round of negotiations in San Francisco in June 2010 it was argued that existing FTAs would remain alongside the TPP, and TPP discussions are still in train.

\section{Bilateral partnerships}

An issue that has only been hinted at above, but that still has a significant impact on Australia's business relations with Latin America is that of the discriminatory impact of bilateral FTAs on trading partners that are not parties to bilateral preferential agreements. Australia and the countries of Latin America are to a greater or lesser extent engaged in bilateral and plurilateral preferential trade agreements with different combinations of countries. While such agreements in

17 DFAT, Annual Report 2008/09, Canberra: Department of Foreign Affairs and Trade, 2009, p. 102.

18 Simon Crean, 'Trade at the Centre of the Global Recovery', Speech to the Foreign Correspondents' Association, Sydney, 16 February 2010; 'Pushing Forward with the Korean FTA and the Trans-Pacific Partnership', Media Release, Department of Foreign Affairs and Trade, Canberra, 15 March 2010. 
principle foster trade relations for the countries involved, in several ways they also discriminate against countries that are not parties to a particular agreement. For example, Mexico's engagement in NAFTA and other preferential trade agreements cover over 90 per cent of its trade. ${ }^{19}$ By favouring trade with the United States and Canada in particular, such agreements implicitly discriminate against Australia and other countries.

This issue makes Australia's bilateral relationship with Mexico more complex than with other Latin American partners. Chapter 5 has shown that after Brazil, Mexico is Australia's largest market in Latin America. Mexico's focus on extracting maximum benefits from NAFTA and its growing concern with competition from China in the US market, complicate its relations with other trading partners, including Australia. Nonetheless, the bilateral relationship is a positive one and trade continues to grow. A 'Joint Expert Group' (JEG) established by the governments of Australia and Mexico under the AustraliaMexico Trade and Investment Agreement (1994) carried out an exhaustive study into strengthening the bilateral economic relationship. ${ }^{20}$ The report identified scope for 'increased economic cooperation' and 'an enhanced trade policy dialogue' through the Joint Trade and Investment Commission established by the 1994 agreement. ${ }^{21}$ A bilateral 'Plan of Action' was concluded in 2011.

Australia's major trade and business interests in Mexico are centred on exports of mining commodities and investment in mining ventures, as well as agriculture and agribusiness services. Australia has an interest in eliminating Mexico's discriminatory import tariffs against, for instance, Australian beef. Mexico's major trade interests in Australia are in attracting more FDI in the mining sector from the major international mining conglomerates such as BHP Billiton and Rio Tinto, and in obtaining relief from Australia's phytosanitary barriers against Mexico's horticultural exports. The bilateral trade and business relationship continues to be hampered by a mutual lack of awareness of trade and investment potential, poor air and sea transport links, as well as a variety of regulatory problems, including customs' procedures, standards, services regulations and public procurement policies. Table 6.3 shows that Australia and Mexico have several operative trade-related bilateral agreements, and in recent years a growing number of relevant MoUs have been added, which might be taken to enhance the trade and business relationship. For example, the renegotiation of the Memorandum of Understanding (MoU) on Mining and the conclusion of a new MoU on Agriculture in 2010, opened a dialogue on reducing regulatory barriers to cross-border trade, including in services in the form of the mutual recognition of professional qualifications. It also opened

19 JEG, op. cit., note 13

20 Ibid.

21 JEG, op. cit., note 12, p. 47. 
a dialogue on options for regulatory cooperation more generally, which may encompass customs' procedures, public procurement policies and standards, including on agriculture.

Ever since it embarked seriously on economic restructuring and trade liberalisation, Chile has continued down the path of trade openness and regulatory reform. While having a smaller population than Australia's other trading partners in the region, the country now has an economy that - after two decades of solid economic and trade reform - is the most open in Latin America. Chile is a founding member of the Cairns Group and, despite its extensive network of FTAs, is a strong supporter of the WTO. It is also a long-standing and active participant in APEC and, like Mexico, a partner with Australia in the TPP negotiations. As with Mexico, Chile is focused mainly on the US market, which takes around 25 per cent of Chile's exports and provides around 15 per cent of Chile's imports. ${ }^{22}$ A significant number of Australian companies have been attracted by the openness of the Chilean market, and have chosen it as a base for their Latin American operations (see chapter 5). In addition, amongst others, BHP Billiton has significant mining investment in Chile-Escondida and Spence copper mines; clothing firm Rip Curl has a licensee that makes and sells its products in Chile; while its competitor Billabong has its own subsidiary venture GSM Chile for that purpose.

The further development of Australia's trade and business relationship with Chile over the immediate period ahead will be largely determined by the FTA (ACI-FTA), which entered into force in 2009. It may also depend on how the TPP negotiations unfold, as they could provide a first step towards multilateralising the commitments already contained in the FTAs that individual TPP-partner countries have with the United States and with each other. The ACI-FTA appears to be consistent with the GATT article XXIV requirement that 'substantially all of the trade' is liberalised and with respect to the commitments on services trade liberalisation, investment and public procurement provisions, it would appear to be a 'WTO plus' agreement. An Australia-Chile air services agreement has been in operation since 2001. There are additional areas where Australia and Chile might build on the provisions of the FTA to develop trade, investment and business relations in the period ahead. This could include action to go beyond the WTO Agreement on Technical Barriers to Trade in pursuing agreements for the mutual recognition of standards. In addition, it could include early action to give effect to the provisions in the FTA to pursue mutual recognition agreements on professional qualifications such as for engineers and architects. Consideration could also be given to developing an 'early warning' system of consultations on regulatory changes that in future could impinge on trade and investment flows between Chile and Australia. 

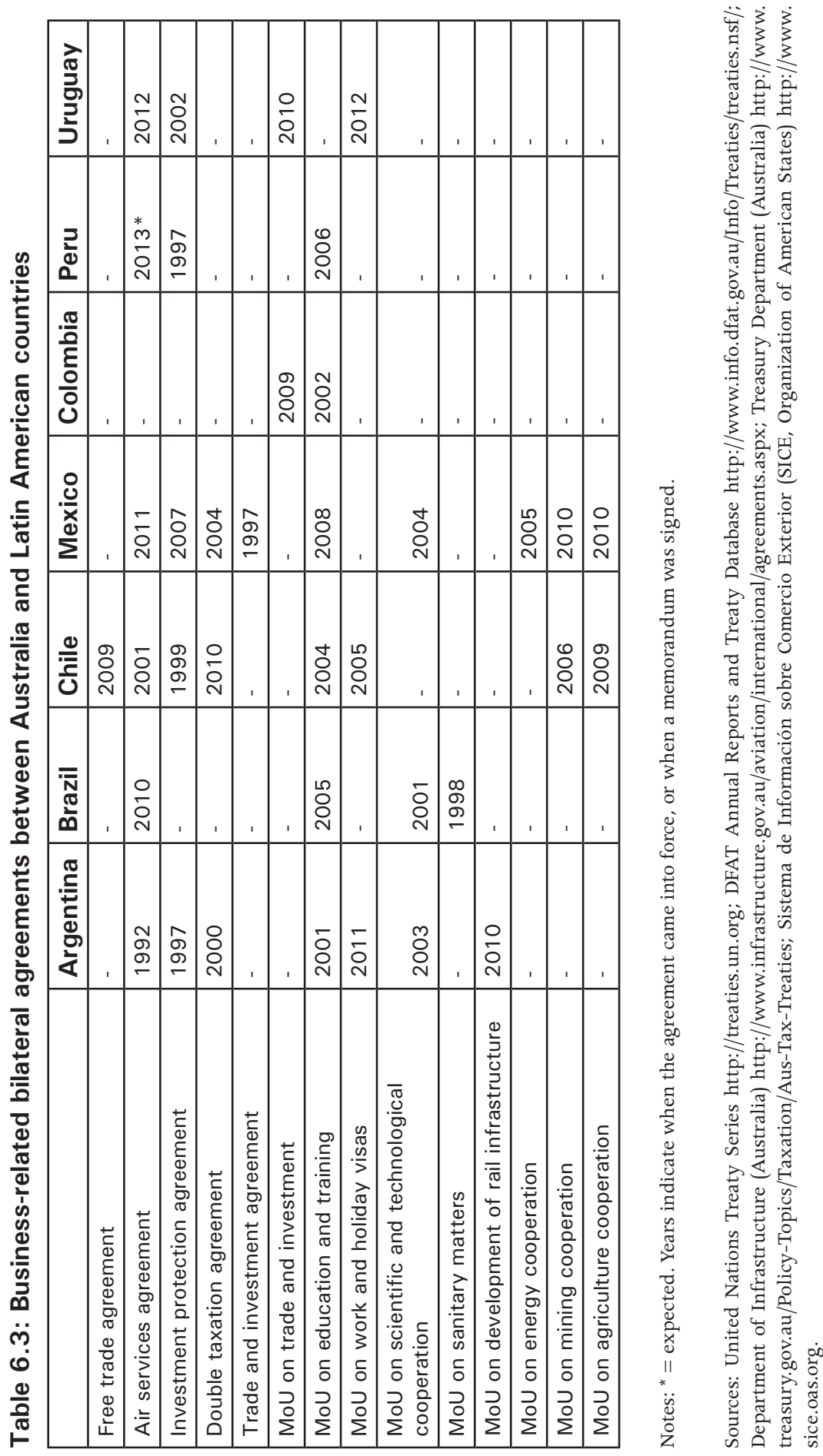
As chapter 5 has shown, Brazil is the largest economy in Latin America. It is also Australia's largest trading partner in Latin America, with continuing scope for a very significant increase in two-way trade. Mutual flows of FDI are growing, as are Australia's imports of manufactured products from Brazil, e.g., civil aircraft. The scope for developing trade and business relationships is enhanced by similarities in the domestic economic and export profile of the two countries. Resources, agriculture and services occupy comparable importance in the GDP and exports of both Brazil and Australia. In contrast, Brazil maintains a more important manufacturing sector. Like Australia, Brazil has a broadly based export profile with North Asia, especially China, which is now playing an increasingly important role compared to Brazil's traditional export markets in North America and Europe. This comparable profile of trading interests opens up significant opportunities for increased trade and investment in mining, mining technology and agribusiness, as well as professional, business, consultancy and financial services.

Unlike Mexico, access to the Brazilian market is not compromised by the existence of preferential FTAs with the large industrial powers of the northern hemisphere. However, Brazil is a member of the Mercosur customs union, along with Argentina, Paraguay and Uruguay, which was established in 1991. Mercosur has created a common external customs tariff - with some remaining exceptions. In tariff terms, Mercosur therefore needs to be dealt with as a single entity across the four countries. The customs union has not attempted to deal with non-tariff barriers to trade.

The major obstacle to growing Australia's trade and business relationship with Brazil is that there are many 'behind the border' non-tariff barriers and domestic regulations that impact on trade. These include investment restrictions, competition policy issues, tax measures, and issues related to public procurement and product standards. Hence, Brazil's transition to a fully open trading system is still a work in progress. Table 6.3 shows that Australia concluded an air services agreement with Brazil in 2010. An agreement for science and technology cooperation is being negotiated and there may be scope for the negotiation of a 'Trade and Investment Facilitation Agreement'. Beyond this, Australia reached an intergovernmental agreement in 2008 to establish a 'Plan of Action to Achieve an Enhanced Partnership'. Moreover, a MercosurCER dialogue was established in 1996 to strengthen cooperation on issues of global trade. It has not met since 2004 and does not appear to have been very effective in advancing the bilateral trade relationship, as exchanges so far appear to have been focused mainly on multilateral trade issues. Nevertheless, there may be scope to reinvigorate this dialogue.

A significant way forward in fostering bilateral trade and business relations between Australia and Brazil would appear to be a focused dialogue on 
regulatory obstacles to increasing trade and investment. Perhaps this could be achieved through both the 'Enhanced Partnership' action plan and a revitalised Mercosur-CER dialogue that would focus more on the bilateral flows of trade and investments between the two trade groupings. A revitalised MercosurCER dialogue could have the advantage of Australia and New Zealand engaging Brazil at the sub-WTO level in dealing with international trade issues. In particular, enhancing and deepening the Mercosur-CER dialogue might offer a fruitful avenue for encouraging the Latin American partner countries to address 'behind the border' regulatory impediments to trade on a Mercosur-CERwide level. Finally, as is the case with Mexico, development of the business relationship between Australia and Brazil is hampered on both sides by lack of awareness of the available opportunities. Maintaining high-level political contacts and involvement from senior ministers from both Australia and Brazil could therefore be useful in giving impetus to the relationship.

Argentina, the fourth major market for Australia in Latin America, would be included in any revitalised Mercosur-CER dialogue. Argentina is in many respects Australia's longest-standing economic partner in Latin America. Their shared interests as important exporters of meat and grains to the world market have thrown them together over many years in bilateral, plurilateral and multilateral efforts to defend their interests. By so doing they have pitted their efficient producers and exporters of agricultural products against the protectionist agricultural policies of the major northern hemisphere producers, exporters and importers of agricultural products. These shared interests have forged close economic and trade bonds between Australia and Argentina over many years. Argentina was also a founding member of the CG in 1986 and a very active participant through the Uruguay Round. Table 3 shows that Australia and Argentina have concluded several bilateral agreements that support bilateral business relations. Along with Brazil and Mexico, Australia and Argentina share membership of the G20 leaders' process, as noted above. Australia and Argentina also have common trade and investment interests in mining and mining technology and services. A major obstacle to the bilateral relationship was Argentina's fragile economic recovery from the major setback it suffered during the financial crisis of 2002-03. For example, its balance of payments problems required import restrictions through licensing, which depressed Australia's exports to Argentina until about 2008. But the continued depreciation of the Argentinian peso relative to the US dollar by 60 per cent since 2008 increased Australian imports from Argentina significantly, but limited the growth of Australia's exports to Argentina.

Two other Latin American countries with capacity to become more important trading partners for Australia are Colombia and Peru. Both appear to be following Chile's path of economic reform and trade openness. Australia has concluded a memorandum of understanding with Colombia aimed at strengthening trade 
and investment links. Australia's mining interests in Peru are growing and an Australia-Peru air services agreement is currently under negotiation. Colombia is also interested in becoming a member of APEC. It is increasingly interested in engaging more with the Western Pacific — as is Colombia - and is a partner with Australia and others in the TPP negotiations. All of this creates foundations for further dialogue that may foster Australia's trade and business relations with both countries.

\section{Conclusion}

Chapter 5 noted that the scope for closer trade and business relations between Australia and Latin America slowly materialised during the past 20-30 years. The complementarity that has always been a major driver of trade expansion and close business links between Australia and the East Asian region has hitherto not extended across the Pacific to the countries of Latin America. Until quite recently - up to the early 1980s - both Australia and key Latin American countries such as Brazil, Argentina, Uruguay and Chile, thought of each other primarily as competitive exporters of agricultural products and mineral resources to the industrialised markets of the northern hemisphere, rather than as close trade and investment partners. Also, until the early 1980s, Australia and the countries of Latin America ran import substitution policies in their manufacturing sectors with high industrial tariffs, which did not encourage trade across the Pacific in non-agricultural products. Much has changed since then.

The global economic challenges of the late 1970s and early 1980s resulted in significant reassessments - both in Australia and in Latin American countries such as Mexico, Brazil, Argentina and Chile - of the way their economies were organised and the nature of their engagement with the global economic and trading environment. From the mid-1980s, programs of domestic economic reform and trade liberalisation were instituted. Trade restrictions were progressively dismantled and high industrial tariffs reduced. New competitive industries in services were created and manufacturing made more efficient. As a result, the economies of Australia and key Latin American countries became more open to international competition and trade. These important changes placed Australia, Brazil, Mexico, Argentina and Chile on comparable paths of economic and trade openness, creating new opportunities for increased trade and investment flows across the Pacific. As chapter 5 has shown, trade has increased and diversified, particularly in Australian exports of services, especially education services to Latin America and in Latin American exports of manufactured products to Australia. 
Chapter 5 analysed a number of reasons why the prospects for increased trade and business relations between Australia and Latin America over the past two decades may have been so slow to materialise. Despite the economic and trade openness resulting from reforms of the 1980s and 1990s, significant differences in business environments remain. Progress in the economic reform programs of some key Latin American countries such as Brazil, Mexico and Argentina has been interrupted by periodic financial crises such as the Asian financial crisis of the mid-1990s, and, in Argentina's case, by the more recent financial crisis of 2002-03. As a consequence, reform processes in many major Latin American economies, particularly in relation to domestic regulatory policies that impact on trade and investment, still have a way to go. Differences in per capita GDP, continuing market rigidities, income inequalities and-in some cases - international payment restrictions, are factors that sustain a significant 'economic distance' between Australia and its major Latin American partners. Latin American countries generally still have less favourable rankings than Australia in international risk, opacity, economic transparency and 'ease of doing business' indexes that reflect perceptions in the business world of the continent. Sustained efforts will be needed to address these hurdles, which in part relate to the incompleteness of economic reform and trade liberalisation programs in a number of Latin American countries. The NAFTA, which binds Mexico in an economic and trade sense very closely to the United States, is another factor limiting the scope for development of the trade and business relationship between Australia and Mexico. The incompleteness of Latin American economic and trade reform programs, remaining 'economic differences' and differing foreign trade priorities have left a legacy of lack of awareness of the expanding opportunities across the Pacific between Australia and Latin America.

Nevertheless, trade and business relations between Australia and Latin America are on the move. An especially interesting factor is the growth in operations of large multinational mining companies such as BHP, Rio Tinto, Vale and Xtrata on both sides of the Pacific. A number of other Australian mining companies and mining technology and services companies are also showing increasing interest in Latin America. Interest at an intergovernmental level on both sides of the Pacific in fostering closer trade relations is also growing through, for example, the intergovernmental Joint Expert Group between Australia and Mexico, and scope for closer dialogue on bilateral trade issues with Brazil and Argentina at the Mercosur level. The ACI-FTA between Australia and Chile, which entered into force in 2009, provides strong evidence of commitment on both sides to deepening the trade/economic relationship beyond tariffs liberalisation to domestic regulatory cooperation.

Beyond these bilateral efforts, a number of plurilateral opportunities for deepening trade and business relations across the Pacific also exist. The TPP negotiations, which formally began in Melbourne in March 2010, could bring 
Chile, Mexico, and Peru together with Australia, Brunei, Canada, Malaysia, New Zealand, Singapore, Vietnam and the United States to comprise what could be a new generation 'WTO plus' regional free trade agreement. In addition, the APEC and G20 summit processes will increasingly provide opportunities for closer dialogue between Australia and the Latin American countries that are members of these forums on structural reforms which, over time, could further strengthen trade and business links across the Pacific. Finally, the WTO provides a unique opportunity for cooperation in the pursuit of shared multilateral trade liberalisation goals. Close Australian-Latin American cooperation in the WTO began with the Cairns Group in the Uruguay Round of trade negotiations (198693) and has continued in the Doha Development Round, not only on agriculture, but also on a number of other services, trade, and GATT rules negotiations issues. Into the future, the WTO provides an opportunity for Australia and Latin American countries to work closely together on common interests relating to WTO accession negotiations, dispute settlement cases; and in helping to set the agenda for future trade negotiating rounds. In all, these developments may enhance the opportunities and incentives for the further growth of Australia's trade and business relations with Latin America in the coming years.

\section{References}

\section{Serials}

EIU, Country Profile (Argentina, Australia, Brazil, Chile, Mexico), London: The Economist Intelligence Unit (annual), 2007-12.

EIU, Country Report (Argentina, Australia, Brazil, Chile, Mexico), London: The Economist Intelligence Unit (monthly), 2008-12.

\section{Other}

Crean, Simon, 'Trade at the Centre of the Global Recovery', Speech to the Foreign Correspondents' Association, Sydney, 16 February 2010.

Crean, Simon, 'Pushing Forward with the Korean FTA and the Trans-Pacific Partnership', Media Release, Department of Foreign Affairs and Trade, Canberra, 15 March 2010.

DFAT, Annual Report 2008/09, Canberra: Department of Foreign Affairs and Trade, 2009. 
Diego-Fernández, Mateo, 'Trade Negotiations Make Strange Bedfellows', World Trade Review, 2008, 7, pp. 423-53.

Hanrahan, Charles E. and Randy Schnepf, WTO Doha Round: The Agricultural Negotiations, Washington DC: Congressional Research Service for Congress, 2006.

Hershberg, Eric and Fred Rosen, (eds), Latin America after Neoliberalism: Turning the Tide in the 21st Century? New York: The New Press, 2006.

JEG, Australia-Mexico Joint Experts Group on Strengthening Bilateral Economic Relations: Joint Report, Canberra/Mexico City: Department of Foreign Affairs and Trade/Ministry of the Economy, 2009.

Kenyon, Don and David Lee, The Struggle for Trade Liberalisation in Agriculture: Australia and the Cairns Group in the Uruguay Round, Canberra: Department of Foreign Affairs and Trade, 2006.

Marconini, Mario, 'Services in Regional Agreements between Latin American and Developed Countries', CEPAL Serie Comercio Internacional No. 71. Santiago (Chile): UN Economic Commission for Latin America and the Caribbean (ECLAC), 2006.

Mortimore, Michael, 'Corporate Strategies for FDI in the Context of Latin America's New Economic Model', World Development, 2000, 28, pp. 1611-26.

Preeg, Ernest H., Traders in a Brave New World: The Uruguay Round and the Future of the International Trading System, Chicago: The University of Chicago Press, 1995.

Sauvé, Pierre, 'Trade and Investment Rules: Latin American Perspectives', CEPAL Serie Comercio Internacional No. 66. Santiago (Chile): UN Economic Commission for Latin America and the Caribbean (ECLAC), 2006.

UNCTAD, World Investment Report 2009, New York: United Nations Conference on Trade and Development, 2009.

Walton, Michael, 'Neoliberalism in Latin America: Good Bad or Incomplete?', Latin American Research Review, 2004, 39 (3), pp. 165-83.

Weyland, Kurt, Assessing Latin American Neoliberalism: Introduction to A Debate', Latin American Research Review, 2004, 39 (3), pp. 143-9.

WTO, International Trade Statistics 2009, Geneva: World Trade Organization, 2009.

WTO, World Tariff Profiles 2012, Geneva: World Trade Organization, 2012. 
This text taken from Australia and Latin America: Challenges and Opportunities in the New Millennium, Edited by Barry Carr \& John Minns, published 2014 by ANU Press, The Australian National University, Canberra, Australia. 